\title{
Article \\ Fluid Properties and Genesis of Dolomites in the Devonian Guanwushan Formation of Upper Yangtze Platform, SW China
}

\author{
Shuguang Huang ${ }^{1}$, Mingcai Hou ${ }^{1, *}$, Anqing Chen ${ }^{1}$, Shenglin Xu ${ }^{1}$, Benjian Zhang ${ }^{2}$, Yuwei Deng ${ }^{3}$ and $\mathrm{Yu} \mathrm{Yu}^{1}$ \\ 1 State Key Laboratory of Oil and Gas Reservoir Geology and Exploitation, Chengdu University of Technology, \\ Chengdu 610059, China; huangshug@163.com (S.H.); aqinth@163.com (A.C.); xusheng218@163.com (S.X.); \\ yuyu@cdut.edu.cn (Y.Y.) \\ 2 Exploration and Development Research Institute, PetroChina Southwest Oil and Gas Field Company, \\ Chengdu 610041, China; zbjian@petrochina.com.cn \\ 3 Sichuan Key Laboratory of Shale Gas Evaluation and Exploitation, Chengdu 610091, China; \\ cdutdyw@163.com \\ * Correspondence: houmc@cdut.edu.cn
}

\section{check for} updates

Citation: Huang, S.; Hou, M.; Chen,

A.; Xu, S.; Zhang, B.; Deng, Y.; Yu, Y. Fluid Properties and Genesis of Dolomites in the Devonian Guanwushan Formation of Upper Yangtze Platform, SW China. Minerals 2022, 12, 317. https:// doi.org/10.3390/min12030317

Academic Editors: Santanu Banerjee, Lei Jiang and Ardiansyah Koeshidayatullah

Received: 10 December 2021 Accepted: 25 February 2022 Published: 3 March 2022

Publisher's Note: MDPI stays neutral with regard to jurisdictional claims in published maps and institutional affiliations.

Copyright: (c) 2022 by the authors. Licensee MDPI, Basel, Switzerland. This article is an open access article distributed under the terms and conditions of the Creative Commons Attribution (CC BY) license (https:// creativecommons.org/licenses/by/ $4.0 /)$.

\begin{abstract}
The Guanwushan Formation (GWSF) of Devonian dolomite are extensively developed in the northwest of Sichuan Basin in the Upper Yangtze region, but the properties of dolomitization fluid and the geneses are still unclear. Three types of dolomites can be divided by petrological characteristics: the fine-microcrystalline dolomites (FMD), the fine crystalline dolomites (FCD) and the medium crystalline dolomites (MCD). The order degree of these three types of dolomites increased in turn, and they all showed dark cathodoluminescence (CL) luminescence. The total amount of Rare Earth Elements ( $\sum R E E$ ) of the dolomite was low, while the dolomite enriched with light REE and lacking heavy REE presented a distribution pattern consistent with that of limestone. The weak negative anomalies of the $\mathrm{Ce}$ and $\mathrm{Eu}$ indicated that the dolomites were formed in a weak redox environment with relatively low temperature. The dolomitization fluids were inherited from the original seawater. The respective $\delta^{13} \mathrm{C}_{\mathrm{PDB}}$ values of the three types of dolomites varied a little, indicating that they were not affected by the biological effects. Specifically, the $\delta^{18} \mathrm{OPDB}_{\mathrm{PD}}$ values of the FMD and FCD dolomites were higher than that of the limestone, indicating that the dolomitization fluid was influenced by evaporation at the penecontemporaneous stage. The interpretations were also supported by the ${ }^{87} \mathrm{Sr} /{ }^{86} \mathrm{Sr}$ ratios, as the ${ }^{87} \mathrm{Sr} /{ }^{86} \mathrm{Sr}$ ratios of FMD comparable to the Middle Devonian seawater. The $\delta^{18} \mathrm{O}_{\mathrm{PDB}}$ value of the MCD dolomite was lower than that of the limestone. It also showed poor automorphic extent, which clarified that the dolomite experienced more intense dolomitization in greater burial depth and at higher temperatures.
\end{abstract}

Keywords: carbonate platform; mineralogy; geochemistry; dolomitization fluid

\section{Introduction}

The origin of dolomites has been a hot topic in the study of sedimentary geology. The dolomite was first described in 1791, and then different theories and models were proposed to explain its origin; however, there remain many controversies at present [1-3]. Extremely rare dolomites were found precipitated in modern sedimentary environments. It is difficult to synthesize the dolomite with perfect order under normal temperature and pressure conditions in the laboratory, while the dolomite is developed in the strata earlier than the Mesozoic. Therefore, most scholars believed that the large number of dolomites developed in geological history were the products of the dolomitization of limestones [4]. Based on that, various dolomitization models have been established, including the hypersaline models by concentrated seawater such as reflux of dolomitization [5], capillary-concentrated dolomitization [6], evaporation pump dolomitization [7]; the normal salinity models such as mixing zone dolomitization [8], normal seawater dolomitization $[9,10]$, the temperatureincreased models by buried stratum or thermal fluids such as buried-compacted dolomi- 
tization [11], adjusted-compacted dolomitization [12,13]; seawater thermal convection dolomitization [14] and hydrothermal dolomitization [15-17]. As the most persuasive and representative of the primary dolomite, the microbial one has attracted close attention from geologists in recent years [18-20]. There are catalytic laboratory simulations of microorganisms and Bacterial Sulfate Reduction (BSR), Zn catalysis [21], and the newly-proposed concepts such as mimetic dolomite [22], dolomite maturity [23], and the application of new methods such as Magnesium isotope, calcium isotope, cluster isotope, U-Pb dating, which have been greatly promoting the progress of dolomitization research [24-29]. Although so many models have been proposed at present, no single one can reasonably explain all of the geneses of dolomites in different regions, different eras, and different depths. Despite the discovery of microbial dolomite in modern sedimentary environments, it does neither show volume significance nor address the origin of thick-layer dolomite in ancient strata. As various dolomitization models are based on different fluid sources of the precursor dolomite in different diagenetic stages, the fundamental problem about the genesis of dolomite is identifying the exact source of dolomitization fluid.

Since the 1950s, many scholars have focused on the Devonian Guanwushan Formation $\left(\mathrm{D}_{2} \mathrm{~g}\right)$ in the Sichuan Basin, mainly in biostratigraphy [30,31], sequence stratigraphy [32-34], sedimentary facies and paleogeography [35-37]. Their research was primarily concentrated in the 1980s and 1990s, but there are relatively few studies on the geneses of the Guanwushan (GWS) dolomites, and there are still considerable controversies [38,39]. The understanding of the genesis and formation models of dolomite could provide insights into the distribution of dolomite reservoirs. Pilot studies of (GWS) dolomites only analyzes the characteristics of petrology and rare earth elements compositions [40,41]. Taking the $\mathrm{D}_{2} \mathrm{~g}$ dolomites in the northwestern part of the Upper Yangtze Platform as the research object, combined with field outcrop, thin sections, CL, X-ray diffraction analysis, whole-rock elemental analysis, and carbon, oxygen and strontium isotope compositions, this study aims to systematically discuss the properties of dolomitization fluid and the geneses of dolomites, to provide insights into the dolomitization models and to guide the subsequent hydrocarbon explorations in the study area.

\section{Geological Setting}

The upper Yangtze platform is situated in northwestern Sichuan, southwestern China, and the study region geographically located in the northeastern part of the Mianyang and Guangyuan areas, Sichuan Basin, reaching Qingchuan in the north, Zitong in the south, Chaotianyi in the east, and Anxian in the west (Figure 1a). The stratum of the Devonian in this area is well developed. The Guixi section in the study area is one of the standard Devonian sections in South China, which makes an ideal place to study the Devonian system. Based on the previous division scheme of the stratum [37], the Devonian system is vertically divided into three series and seven groups. These are respectively named: the Pingyipu and Ganxi formations of the Lower Devonian, the Yangmaba, the Jinbaoshi, and the Guanwushan formations of the Middle Devonian, and the Shawuozi and the Maoba formations of the Upper Devonian. After the deposition of the GWSF, due to the uplift of the Liujiang movement, it was denuded to a certain extent and contacted with the overlying Carboniferous as a parallel unconformity [42]. 

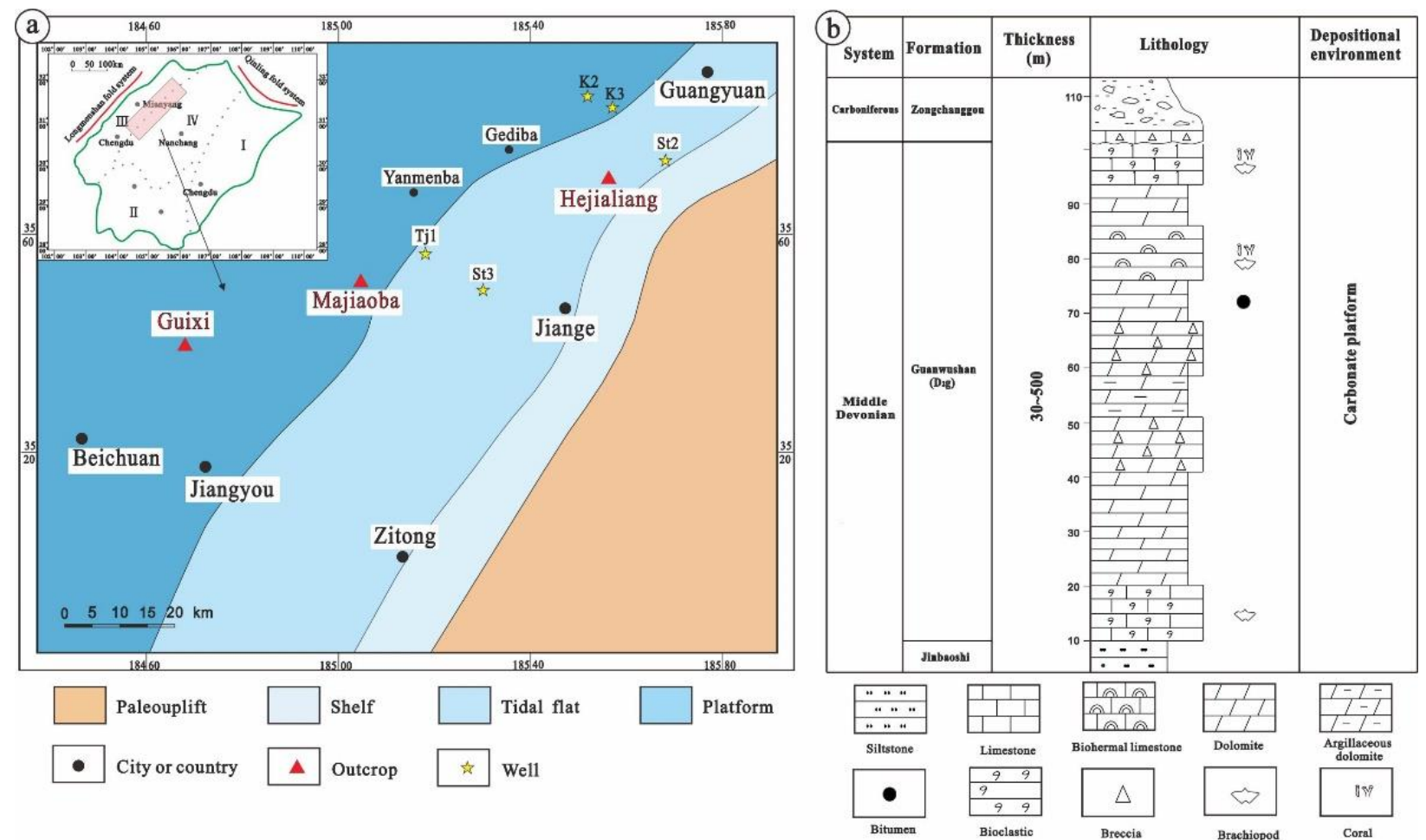

Figure 1. (a) Location and paleogeographic setting of the study area during deposition of the GWSF; (b) Schematic of the stratigraphy and sedimentology of the GWSF.

At the end of the Caledonian orogeny, the upper Yangtze plate was uplifted and went through exposure. With the opening of the Palaeo-Tethys Ocean in the early Devonian, the seawater from the west margin of the upper Yangtze plate invaded to the east of the Qilian Sea, and strata were first deposited on the western margin. During the early stage of the $\mathrm{D}_{2}$ g period, the sedimentary environment changed from rejuvenated river faces on an exposed shelf to nearshore terrigenous faces. Still, from then to the Maoba period, the carbonates deposited along the Longmen mountain, and the carbonate ramp at the late Jinbaoshi period quickly aggraded into carbonate platform at $\mathrm{D}_{2} \mathrm{~g}$ period. Carbonates deposited in the middle and late $\mathrm{D}_{2} \mathrm{~g}$ period had resulted in the third significant reef buildup at the Longmen mountain area and given priority to the development of platform margin reefs. Due to the barrier from the platform margin reefs, the depression inside the platform became shallow. The water flowed inadequately while the salinity increased and transformed into a confined platform environment that was unsuitable for the growth of reef-building organisms. The dolomitization of sediments was both intense and widespread, forming massive fine-coarse crystalline dolomites (Figure 1b).

Therefore, the western margin of the upper Yangtze is a typical epicontinental platform of marine carbonate-platform margin sedimentary environment during the Guanwushan period.

\section{Samples and Methods}

The samples of the GWSF involved in this study were collected from outcrop sections of Guixi (GX), Majiaoba (MJB), Hejialiang (HJL) and the ST3 well. Based on microscopic identification, 36 samples were selected for analyses of major, trace and rare earth elements, $\mathrm{C}$ and $\mathrm{O}$ isotopes. The sample was crushed to the centimeter level to avoid cracks and veins preferably. It was firstly sampled with a micro-drill and manually pestled to less than 200 mesh with an agate mortar. It was then divided into 5 parts for the major elements, trace and rare earth elements, C, O, Sr isotopes, X-ray Diffraction Analysis, and the remaining 1 spare. 
The major elements were tested by X-ray fluorescence spectroscopy, and the 36 samples powder were mixed with lithium tetraborate and lithium metaborate before compacting and then tested by the Thermo ARL ADVANT'XP+ sequential X-ray fluorescence spectrometer (Thermo Fisher Scientific Inc., Waltham, MA, USA). The standard error of $\mathrm{CaO}$ and $\mathrm{SiO}_{2}$ is less than $2 \%$, and that of other oxides is $10 \%$.

Trace elements of the same 36 samples (including REEs) were tested by acid dissolution with a high-resolution plasma mass spectrometer VG Axiom. Additionally, $60 \mathrm{mg}$ of sample powder was digested with $0.5 \mathrm{~mL}$ of $\mathrm{HNO}_{3}$ and then dried. Then, $5 \mathrm{~mL}$ of 1 mole per liter of $\mathrm{HNO}_{3}$ was added to the dried sample and heated at $130{ }^{\circ} \mathrm{C}$ for $3 \mathrm{~h}$. Finally, the solution was diluted with ultrapure $\mathrm{H}_{2} \mathrm{O}$ to a volume of $50 \mathrm{~mL}$ for trace element analysis.

The inorganic $\mathrm{C}$ and $\mathrm{O}$ isotope analyses were carried out with MAT253 isotope ratio mass spectrometer (Thermo Fisher Scientific Inc., Waltham, MA, USA), and the standard sample was GBW04406. 36 Powered samples were reacted with $99 \% \mathrm{H}_{3} \mathrm{PO}_{4}$ at $75{ }^{\circ} \mathrm{C}$ for $16 \mathrm{~h}$. The test results were based on the international V-PDB and recorded as $\delta^{13} \mathrm{C}_{\mathrm{V}-\mathrm{PDB}}$ and $\delta^{18} \mathrm{O}_{\text {V-PDB. }}$. The analytical accuracy was better than $\pm 0.1 \%$.

The dolomite mineral composition and order degree of dolomites of 24 samples were analyzed by X-ray diffractometer at Mineral Resources Chemical Laboratory of the Chengdu University of Technology (CDUT). The CL8200 MK5 cathode luminometer conducted the CL microscopy of the samples under the working conditions of $11 \mathrm{Kv}$ and $280 \mathrm{~mA}$ at the Chengdu Geological Survey Center of China Geological Survey.

Moreover, $50 \mathrm{mg}$ of 17 samples powder were prepared for strontium isotope analysis. These were dissolved in $6 \mathrm{~N} \mathrm{HCl}$ on the hotplate at $60{ }^{\circ} \mathrm{C}$ for $24 \mathrm{~h}$. The purification and separation of strontium from the sample matrix were operated on the AG50Wx12 mesh cation exchange resin. The ${ }^{87} \mathrm{Sr} /{ }^{86} \mathrm{Sr}$ ratios were analyzed on a Finnigan MAT-253 mass spectrometer at State Key Laboratory of Oil and Gas Reservoir Geology and Exploitation, CDUT. The international standardized sample NBS-987 was routinely analyzed through Sr isotopic measurement, yielding an average value of $0.71029240 \pm 0.000018(2 \sigma)$.

\section{Results}

\subsection{Petrological and Mineralogical Characteristics of Dolomites}

\subsubsection{Petrological Characteristic and Classification of Dolomites}

The dolomites classification is based on the size and structure proposed by Sibley [43]. Based on the microscope observation, they are mainly divided into three types: fine crystalline-microcrystalline one (FMD), fine crystalline one (FCD), and medium crystalline one (MCD).

\section{Fine Crystalline-Microcrystalline Dolomite (FMD)}

The FMD is mainly developed in the middle of the GWSF. The color of outcrop hand specimens is gray-white, and the core is dark-gray with thick layers. The layers are sometimes algal dolomite and occasionally raw debris. Under the polarized microscope, the dolomite crystals mainly consisted of microcrystalline, and some of them were fine crystalline. The overall crystal size was found smaller than $0.1 \mathrm{~mm}$ (Figure $2 \mathrm{~d}$ ). Its original structure was well preserved, and the common debris remained, while some large organisms (individual biological shells up to several millimeters in length) had not undergone the dolomitization. The structure of the algae layer was obvious, consisting of the bright and dark layers of dolomite crystals (Figure 2e); the dark part of dolomite was microcrystalline, while the bright and clean part of dolomite was fine crystalline. Some samples contained tiny terrestrial siliceous debris. Under CL, FMD crystals commonly exhibited zero to very dull-red luminescence (Figure 3a,b). Generally speaking, FMD was tighter with fewer pores. It was mostly found in the flat tidal environment of the restricted platform, where the water energy was weak and the evaporation was intense. 


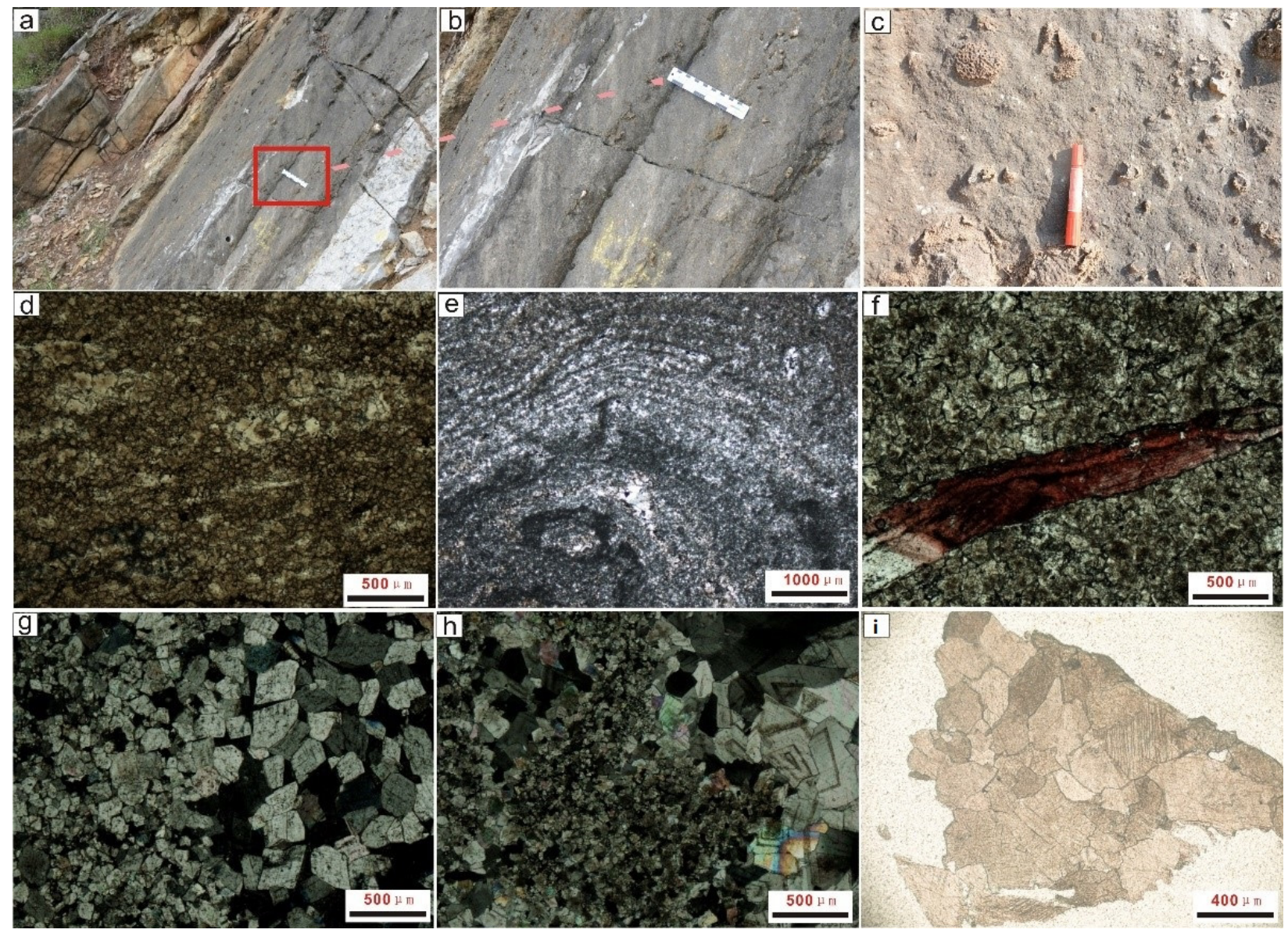

Figure 2. Photographs showing general petrographic features of GWS dolomites in the Sichuan basin: (a) middle-bedded reef dolomite from HJL outcrop; (b) an amplification of a; (c) organisms in the bedding surface of a; (d) Microcrystalline dolomite from GX outcrop; (e) microcrystalline dolomite from HJL outcrop with algae layer consisting of the bright and dark layers of dolomite crystals; (f) fine crystalline dolomite from MJB outcrop with cloudy centers surrounded by clear rims; (g) fine crystalline dolomite from HJL outcrop with intercrystal pore; (h) medium crystalline dolomite and saddle dolomite from HJL outcrop with curved crystal surface; (i) medium crystalline dolomite from the well.

Fine Crystalline Dolomite (FCD)

The FCD dolomite was generally grey to grey-white of middle bedding in the outcrops (Figure 2a,b), many biological fragments can be seen in the layer (Figure 2c). The FCD dolomite was mainly fine crystalline, containing only a small number of microcrystalline crystals. Its crystal size was mostly between 0.08 to $0.2 \mathrm{~mm}$, which was characterized by the euhedral and subhedral textures. In some samples, FCD's turbid core and bright rim structure were visible. The center of the crystal looked dirty, and the outside was revolved by a relatively bright ring (Figure $2 \mathrm{f}$ ). This dolomite owned a high order degree and often exhibited a very regular shape of a diamond. However, compared with the type of FMD, all the different types of organisms, bioclastic and sputum, were dolomitized into FCD. Such dolomite crystals were closely attached, mostly in line contacts or even inlaid contacts (Figure 2g). Under CL, these dolomite crystals showed the dull-red to zero-luminescence at the centers and the bright-red at the thin rims (Figure $3 c, d$ ). The pore types were mainly inter-crystalline pores, and the pores enlarged by inter-granular dissolution developed along the fracture. This dolomite was the most dominant type in the GWSF of the study area. 

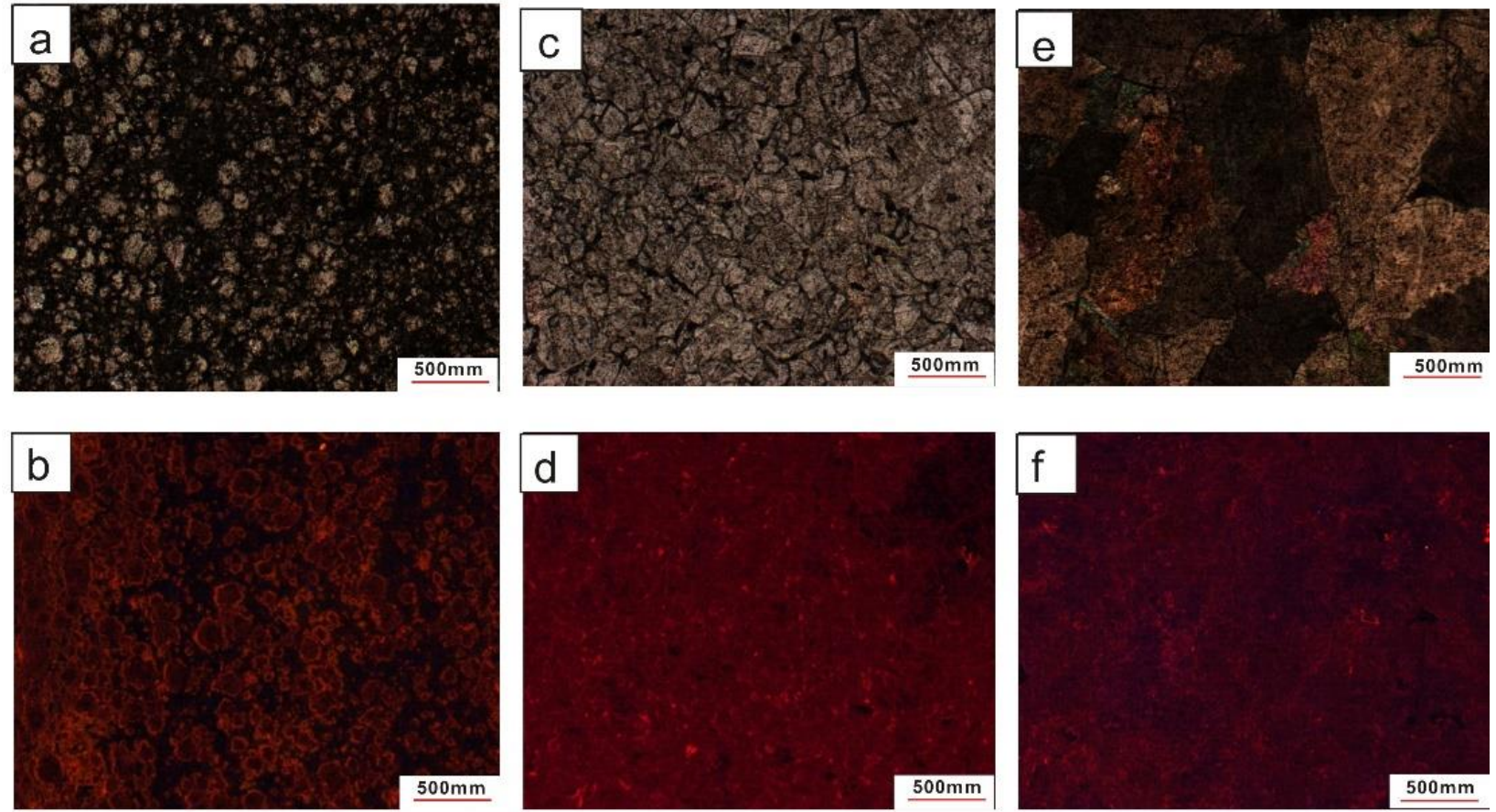

Figure 3. Photographs showing general petrographic features of GWS dolomites in Sichuan basin: (a) Microcrystalline dolomite, dolomite crystals showed the dull-red to zero-luminescence at the centers and the bright-red at the thin rims; (b) CL of Microcrystalline dolomite; (c) Fine crystalline dolomite; (d) CL of Fine crystalline dolomite; (e) Medium crystalline dolomite; (f) CL of Medium crystalline dolomite, the crystals exhibited mottled dull-red luminescence.

Medium Crystalline Dolomite (MCD)

The crystal size of MCD seemed mainly medium crystalline, containing a small amount of fine crystalline or coarse crystalline crystals. The size range was mostly concentrated within $0.25-0.45 \mathrm{~mm}$ and generally exhibited the anhedral and subhedral textures (Figure 2h). The original structure of MCD had been completely modified, like fabricdestructive, and only the ghost outlines of biological particles could be seen sporadically. The cloudy centers surrounded by clear rims were common. The clear rims were wider than that of FCD, which grew around the early subhedral dolomite, causing the crystal to enlarge. Under the cross-polarized light, the dolomite exhibited an obvious undulatory extinction. Under CL, the dolomite crystals commonly exhibited mottled dull-red luminescence, between which the bright-red luminescent thin rims were locally surrounded (Figure $3 \mathrm{e}, \mathrm{f})$. The pore were mainly inter-crystalline ones, and the pores enlarged by inter-granular dissolution also developed along the fracture (Figure 2i).

In addition, there were many dolomite or calcite fillings, which appeared in the form of crack veins or inter-granular dissolution pores. These dolomite fillings were majorly Saddle Dolomites (SD), mainly developed within the inter-crystalline pores (karst caves) and cracks. The crystals were larger than the surrounding matrix, mainly medium-coarse crystalline, at a size of more than $0.3 \mathrm{~mm}$. There were many small inclusions within the interiors, which indicated that the SD was formed rapidly, and a small number of structural fractures was also seen. There were two types of calcite veins; one was thin curved, and discontinuous, at the width of about $0.15 \mathrm{~mm}$, while the later-formed dolomite mostly cut it; the other was a wider calcite vein. Its width was greater than $0.8 \mathrm{~mm}$, and its interior was filled with coarse crystalline matrix calcite.

\subsubsection{Degree of Order in the Dolomites}

The order degree of dolomites is related to their crystallinity. To some extent, it reflects the chemical and physical conditions of source environments. In the ideal dolomite, the 
number of $\mathrm{Ca}^{2+}$ ions and $\mathrm{Mg}^{2+}$ ions were equal, the molar percents of $\mathrm{Ca}$ and $\mathrm{Mg}$ were $50 \%$, and the three ions of $\mathrm{Ca}^{2+}, \mathrm{Mg}^{2+}$, and $\mathrm{CO}_{3}{ }^{2-}$ appeared completely in the (001) direction of the crystal lattice. In an ordered arrangement, a superstructure reflection peak appeared on the X-ray diffraction pattern, and this study defined the order degree of the dolomite in this case as 1 . By contrast, in the lattice (001) direction, $\mathrm{CaCO}_{3}$ and $\mathrm{MgCO}_{3}$ were completely and randomly arranged, while the probability of finding $\mathrm{Ca}^{2+}$ ions, $\mathrm{Mg}^{2+}$ ions, and $\mathrm{CO}_{3}{ }^{2-}$ ions at any point in the crystal was the same. This case defined it as 0 in this case. The degree of order, a significant sign of the crystallinity of dolomite, reflects the arrangement variability of $\mathrm{Ca}^{2+}$ and $\mathrm{Mg}^{2+}$ ions in dolomite crystal lattices, which of most natural dolomites is between 0 and 1 (the completely ordered dolomite).

Previous studies have suggested that the order degree of dolomites was affected to some extent by the stratum age, the depositing time and rate of dolomitization, the temperature, the pressure and the impurity ions. The order degree of the dolomite with high stability was greater than that with lower stability. For example, as the burial depth of the formation increased, the ground temperature also increased. Combined with the pore fluids in the formation, the $\mathrm{Mg}^{2+}$ ions continuously replaced the $\mathrm{Ca}^{2+}$ ions, and the highcalcium dolomite would transform to the stable state of $\mathrm{Ca}^{2+} / \mathrm{Mg}^{2+}$, tending to 1 . Therefore, the older the formation, the deeper it was buried, and consequently, the stronger the effect of the recrystallization, then the higher-order degree of the corresponding dolomite.

The experiment data indicated the order degree of FMD was $0.44-0.59$, with an average of 0.50 . The order degree of FCD is $0.44-0.80$, and the average value is 0.64 . The order degree of the MCD was $0.70-0.81$, with an average of 0.76 . The order degree of these three increased in turn (Figure 4).

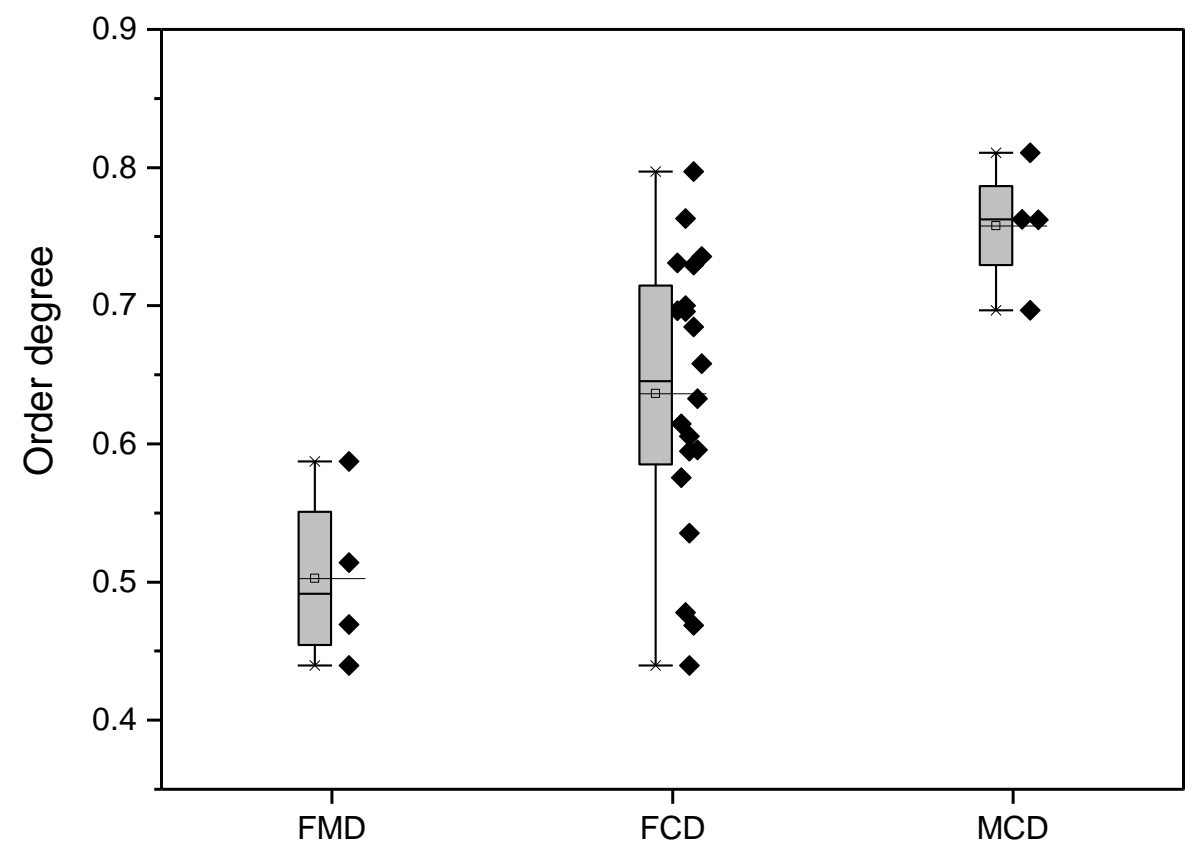

Figure 4. Order degree of three types of dolomites in the $\mathrm{D}_{2} \mathrm{~g}$ in the northwestern Sichuan Basin.

\subsection{Geochemical Characteristics of Dolomite}

\subsubsection{Trace Elements}

The contents of Fe, Mn, Sr, Al, and other elements was an important proxy for the diagenetic analysis of carbonate rocks. The ionic radius of $\mathrm{Fe}^{2+}$ and $\mathrm{Mn}^{2+}$ was smaller than that of $\mathrm{Ca}^{2+}$, which was more likely to be substituted for the position of $\mathrm{Ca}^{2+}$ and be enriched in the carbonate minerals. On the contrary, the ionic radius of $\mathrm{Sr}^{2+}$ was larger than that of $\mathrm{Ca}^{2+}$, $\mathrm{Fe}^{2+}, \mathrm{Mn}^{2+}$, etc., and the other ions with a smaller radius would replace the $\mathrm{Sr}^{2+}$, which caused the loss of $\mathrm{Sr}^{2+}$. As the burial depth increased, the diagenesis was strengthened accordingly. The water-rock reaction caused the rock to be more or less affected by the later 
diagenetic fluid, resulting in the higher contents of Fe and $\mathrm{Mn}$ in the carbonate. Sr tended to join the fluid phase, and its content in the carbonate gradually decreased.

The measured trace element contents of dolomites are shown in Table 1 and Figure 5. The dolomite and limestone samples of the $\mathrm{D}_{2} \mathrm{~g}$ in the northwestern Sichuan Basin were basically unaffected by the diagenetic alterations according to the discovery of changes in $\mathrm{Mn}$ and Sr contents. The muddy limestone samples could better represent the feature of primary seawater sediments. The Fe content of the limestone ranged from 2993.4 to $6766.1 \mathrm{ppm}$, with an average of $4879.8 \mathrm{ppm}$, the Mn content ranged from 49.9 to $85.5 \mathrm{ppm}$, with an average of $66.2 \mathrm{ppm}$, and the Sr content ranged from 133.8 to $254.9 \mathrm{ppm}$, with an average of $194.4 \mathrm{ppm}$, respectively. The Fe values of the FMD were within the range of 2003.1 to $3791.4 \mathrm{ppm}$, with an average of $2756.9 \mathrm{ppm}$, the Mn content ranging from 55.7 to 102.8 $\mathrm{ppm}$, with an average of $82.1 \mathrm{ppm}$, and the Sr content ranging from 62.1 to $172.3 \mathrm{ppm}$, with an average of $120.7 \mathrm{ppm}$, separately. The content of the Fe in the fine crystalline dolomite ranged from 1568.4 to14495.1 ppm, with an average of $5252.8 \mathrm{ppm}$, the Mn content ranged from 70.7 to $779.2 \mathrm{ppm}$, with an average of $209.3 \mathrm{ppm}$, the Sr content ranged from 45.9 to $162.5 \mathrm{ppm}$, with the average of $97.6 \mathrm{ppm}$, individually; the Fe concentrations in the MCD samples ranged from 2162.7 to $5064.7 \mathrm{ppm}$, with an average of $3551.0 \mathrm{ppm}$, the Mn content ranging from 96.9 to $473.7 \mathrm{ppm}$, with an average of $229.3 \mathrm{ppm}$, and the Sr content ranging from 68.7 to $89.4 \mathrm{ppm}$, with an average of $80.4 \mathrm{ppm}$, respectively.

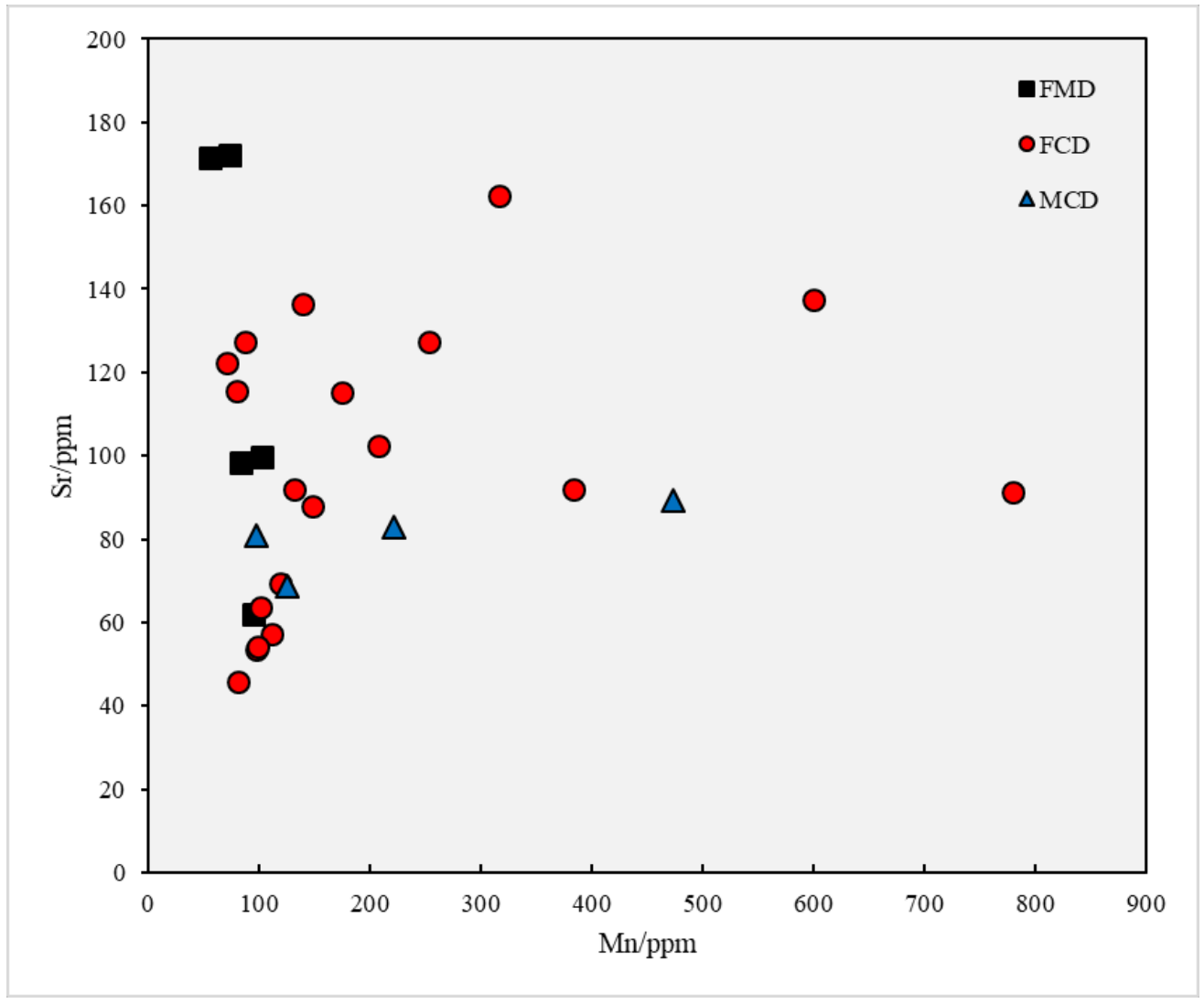

Figure 5. Cross-plot of Mn and Sr values for dolomites. FMD: Fine-microcrystalline dolomite; FCD: Fine crystalline dolomite; MCD: Medium crystalline dolomite. 
Table 1. Isotopic data $\left(\delta^{13} \mathrm{C}, \delta^{18} \mathrm{O}\right.$ and $\left.{ }^{87} \mathrm{Sr} /{ }^{86} \mathrm{Sr}\right)$ of dolomites in the Middle Devonian carbonate successions, northwestern Sichuan Basin.

\begin{tabular}{|c|c|c|c|c|c|c|c|c|c|c|}
\hline Sample & Lithology & Section/Well & $\operatorname{Mn}(p p m)$ & $\mathrm{Fe}(\mathrm{ppm})$ & Sr(ppm) & $\mathrm{Mn} / \mathrm{Sr}$ & $\delta^{13} \mathrm{C}(\%$ VPDB) & $\delta^{18} \mathrm{O}(\% \circ \mathrm{VPDB})$ & ${ }^{87} \mathrm{Sr} /{ }^{86} \mathrm{Sr}( \pm 2 \sigma)$ & Order Degree \\
\hline HJL8-4 & Lime & HJL & 85.53 & 6766.13 & 254.98 & 0.335 & -0.49 & -6.33 & $0.708572 \pm 19$ & \\
\hline MJB-12 & Lime & MJB & 49.87 & 2993.39 & 133.78 & 0.373 & -2.18 & -5.65 & / & \\
\hline HJL9-3 & FMD & HJL & 83.13 & 3791.38 & 98.24 & 0.85 & 3.36 & -2.12 & / & 0.514 \\
\hline MJB-05 & FMD & MJB & 95.16 & 2165.04 & 62.06 & 1.53 & 1.51 & -5.22 & / & / \\
\hline GX-13 & FMD & GX & 102.76 & 3313.75 & 99.70 & 1.03 & 2.40 & -1.04 & / & 0.587 \\
\hline GX-14 & FMD & $\mathrm{GX}$ & 55.70 & 2003.07 & 171.41 & 0.32 & 2.45 & -0.59 & 1 & 0.469 \\
\hline GX-15 & FMD & GX & 73.54 & 2511.23 & 172.28 & 0.43 & 2.31 & -1.65 & $0.708086 \pm 17$ & 0.440 \\
\hline 7574.8 & FMD & ST1 & / & / & / & & 0.96 & -3.77 & / & / \\
\hline HJL9-1 & FCD & HJL & 316.72 & 5957.34 & 162.47 & 1.95 & 0.95 & -5.82 & $0.708335 \pm 16$ & 0.575 \\
\hline HJL10-2 & FCD & HJL & 139.34 & 2913.00 & 136.35 & 1.02 & 0.08 & -1.29 & $0.708734 \pm 18$ & 0.595 \\
\hline HJL13-2 & FCD & HJL & 97.23 & 1871.05 & 53.42 & 1.82 & 2.62 & -7.44 & $0.708187 \pm 14$ & 0.797 \\
\hline HJL13-7 & FCD & HJL & 79.41 & 6328.27 & 115.64 & 0.69 & 1.55 & -4.34 & $0.709076 \pm 19$ & 0.606 \\
\hline HJL15-1 & FCD & HJL & 87.20 & 5543.94 & 127.42 & 0.68 & 1.83 & 0.28 & $0.708408 \pm 16$ & 0.535 \\
\hline HJL16-1 & FCD & HJL & 599.45 & 14495.13 & 137.37 & 4.36 & -1.34 & 1.58 & / & 0.440 \\
\hline HJL17-1 & FCD & HJL & 70.71 & 9136.83 & 122.30 & 0.58 & 2.24 & 0.37 & $0.708557 \pm 18$ & 0.469 \\
\hline HJL18-1 & FCD & HJL & 383.05 & 4942.74 & 91.81 & 4.17 & 0.71 & -5.51 & / & 0.730 \\
\hline HJL18-2B & FCD & HJL & 207.84 & 13497.81 & 102.43 & 2.03 & 0.29 & -5.98 & / & 0.696 \\
\hline HJL18-4 & FCD & HJL & 174.69 & 7556.98 & 115.37 & 1.51 & 1.55 & 0.19 & / & 0.478 \\
\hline HJL19-2 & FCD & HJL & 252.65 & 8208.77 & 127.39 & 1.98 & 0.29 & 0.11 & / & 0.700 \\
\hline HJL21-1 & FCD & HJL & / & / & / & / & / & / & $0.70838 \pm 14$ & \\
\hline MJB-09 & FCD & MJB & 131.56 & 3170.95 & 91.93 & 1.43 & 0.39 & -3.63 & $0.708478 \pm 17$ & 0.736 \\
\hline MJB-11 & FCD & MJB & 110.94 & 2027.57 & 57.34 & 1.93 & 0.26 & -6.51 & $0.708217 \pm 18$ & 0.614 \\
\hline GX-06 & FCD & GX & 98.66 & 2010.18 & 54.23 & 1.82 & 1.64 & -9.09 & / & 0.633 \\
\hline GX-08 & FCD & $\mathrm{GX}$ & 80.45 & 1568.42 & 45.94 & 1.75 & 2.29 & -9.48 & 1 & 0.731 \\
\hline GX-10 & FCD & GX & 101.10 & 2583.03 & 63.69 & 1.59 & 3.98 & -8.53 & $0.709172 \pm 19$ & 0.658 \\
\hline 7572.04 & FCD & ST1 & / & / & / & / & 2.45 & -4.15 & / & / \\
\hline 7578.13 & FCD & ST1 & / & / & / & 1 & 0.97 & -3.97 & 1 & 1 \\
\hline 7579.73 & FCD & ST1 & / & / & / & / & -1.20 & -3.94 & $0.709012 \pm 17$ & / \\
\hline 7582.68 & FCD & ST1 & / & / & / & 1 & -2.56 & -3.78 & / & 0.696 \\
\hline 7588.5 & FCD & ST1 & / & / & / & / & -1.65 & -3.84 & $0.708798 \pm 15$ & / \\
\hline HJL12-2 & MCD & HJL & 221.46 & 4286.53 & 82.79 & 2.67 & 1.66 & -6.21 & 1 & 0.811 \\
\hline HJL13-3A & $\mathrm{MCD}$ & HJL & 96.90 & 5064.68 & 80.90 & 1.20 & 2.42 & -6.12 & $0.709193 \pm 16$ & 0.762 \\
\hline HJL13-5 & MCD & HJL & 124.95 & 2162.66 & 68.66 & 1.82 & 2.24 & -7.39 & $0.708267 \pm 19$ & 0.697 \\
\hline HJL14-1 & MCD & $\mathrm{HJL}$ & 473.72 & 2690.19 & 89.44 & 5.30 & 1.96 & -6.30 & $0.710546 \pm 13$ & 0.763 \\
\hline
\end{tabular}


The Mn/Sr ratios of three types of dolomites showed that the Sr content of FMD was the highest, the Sr content of MCD was the lowest, and the Sr contents of FMD, FCD, and MCD reduced in turn (Figure 5). The Mn content of limestone was the lowest, followed by that of FMD. The FCD had a slightly lower Mn content than MCD. As the depth of burial added, the content of $\mathrm{Mn}$ in the dolomite increased gradually, and the Sr content decreased relatively. However, compared with the dolomites in other researched areas, the values of Sr and Mn from different types of dolomites in the GWSF have changed relatively slightly. Furthermore, there was not much difference in that of limestone, indicating that the diagenetic fluids might come from the ancient seawater of middle Devonian, which was near-surface or imprisoned in the strata.

\subsubsection{REEs}

As an essential index of geochemical tracer, the REEs have been widely used to analyze the ore genes and the source of the clastic rock. In recent years, some efforts have been made to explore the origin of dolomite and its diagenesis evolution. Scholars have been trying to apply REEs to reveal the source of diagenesis fluids, and it has achieved an effective result $[44,45]$. The content of REEs in the study area is shown in Table 2 and Figure 6.
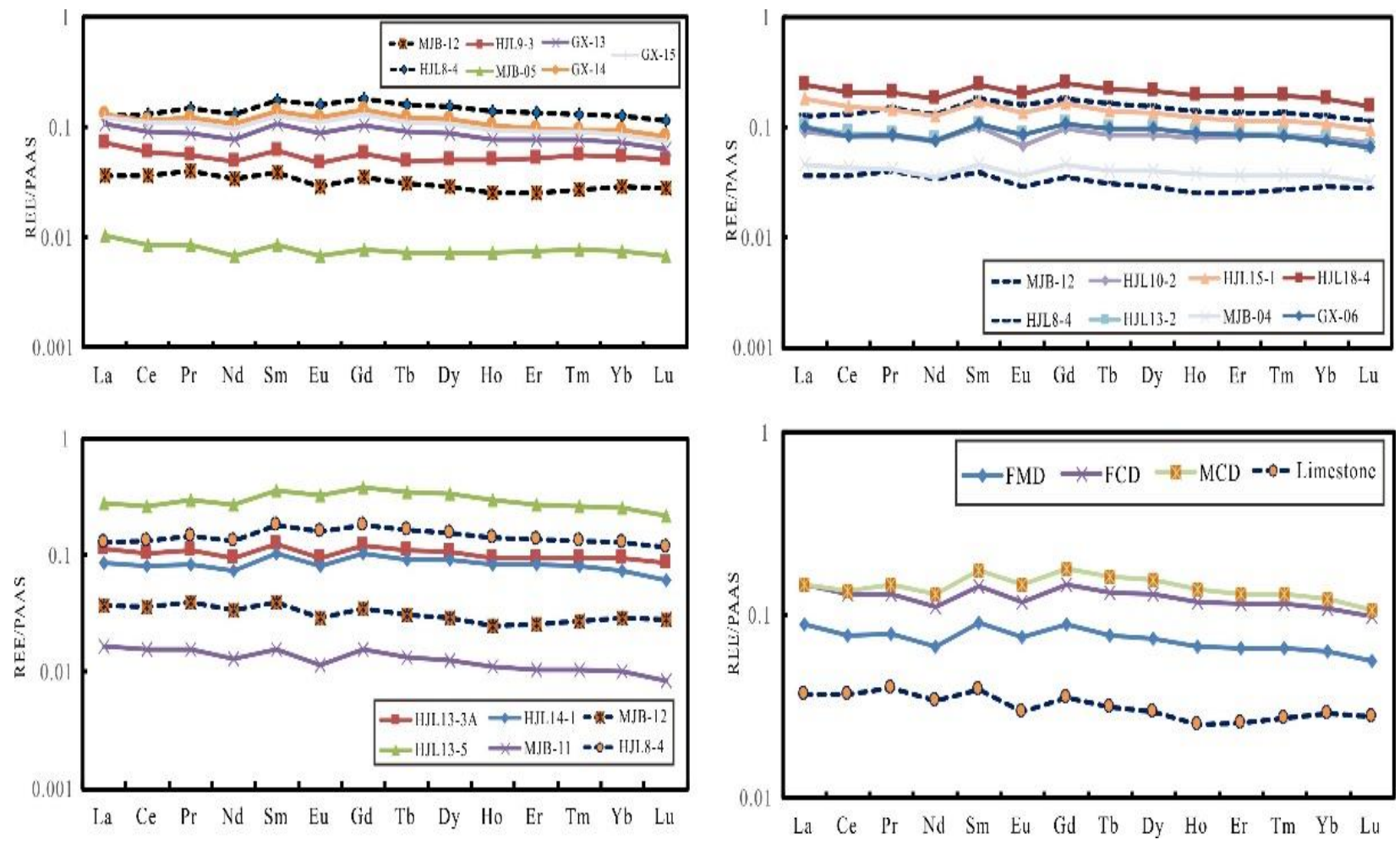

Figure 6. North America Shale Composite-normalized REE assemblage patterns of the Devonian Guanwushan Formation $\left(\mathrm{D}_{2} \mathrm{~g}\right)$ dolomites in the northwestern Sichuan Basin. 
Table 2. REE composition (ppm) of the carbonate of the GWSF.

\begin{tabular}{|c|c|c|c|c|c|c|c|c|c|c|c|c|c|c|c|}
\hline Sample & La & $\mathrm{Ce}$ & Pr & $\mathrm{Nd}$ & Sm & $\mathrm{Eu}$ & Gd & $\mathbf{T b}$ & Dy & Ho & Er & $\mathrm{Tm}$ & $\mathrm{Yb}$ & $\mathbf{L u}$ & $\mathbf{Y}$ \\
\hline HJL8-4 & 4.433 & 9.415 & 1.170 & 4.431 & 1.150 & 0.217 & 1.058 & 0.158 & 0.918 & 0.180 & 0.481 & 0.067 & 0.415 & 0.061 & 7.840 \\
\hline MJB-12 & 1.287 & 2.606 & 0.314 & 1.152 & 0.250 & 0.040 & 0.206 & 0.030 & 0.173 & 0.032 & 0.089 & 0.014 & 0.095 & 0.015 & 1.549 \\
\hline HJL9-3 & 2.501 & 4.317 & 0.450 & 1.647 & 0.400 & 0.065 & 0.338 & 0.048 & 0.294 & 0.064 & 0.180 & 0.028 & 0.177 & 0.026 & 3.622 \\
\hline MJB-05 & 0.360 & 0.613 & 0.068 & 0.231 & 0.055 & 0.009 & 0.045 & 0.007 & 0.043 & 0.009 & 0.026 & 0.004 & 0.025 & 0.004 & 0.586 \\
\hline GX-13 & 3.782 & 6.513 & 0.708 & 2.609 & 0.680 & 0.121 & 0.604 & 0.090 & 0.526 & 0.099 & 0.274 & 0.039 & 0.235 & 0.033 & 8.123 \\
\hline GX-14 & 4.600 & 8.314 & 0.987 & 3.624 & 0.905 & 0.168 & 0.843 & 0.120 & 0.696 & 0.133 & 0.347 & 0.048 & 0.305 & 0.043 & 9.116 \\
\hline GX-15 & 4.308 & 8.009 & 0.886 & 3.257 & 0.826 & 0.151 & 0.774 & 0.109 & 0.636 & 0.122 & 0.321 & 0.046 & 0.280 & 0.039 & 8.941 \\
\hline HJL9-1 & 3.995 & 8.229 & 0.940 & 3.353 & 0.781 & 0.136 & 0.690 & 0.099 & 0.573 & 0.115 & 0.320 & 0.048 & 0.310 & 0.045 & 5.644 \\
\hline HJL11-3 & 3.127 & 6.107 & 0.652 & 2.386 & 0.605 & 0.100 & 0.567 & 0.080 & 0.471 & 0.090 & 0.241 & 0.032 & 0.195 & 0.028 & 6.812 \\
\hline HJL13-2 & 3.523 & 6.248 & 0.675 & 2.607 & 0.670 & 0.116 & 0.634 & 0.095 & 0.577 & 0.113 & 0.311 & 0.043 & 0.251 & 0.034 & 10.655 \\
\hline HJL13-7 & 5.945 & 10.872 & 1.269 & 4.810 & 1.212 & 0.215 & 1.011 & 0.155 & 0.895 & 0.170 & 0.431 & 0.060 & 0.346 & 0.048 & 12.389 \\
\hline HJL15-1 & 6.307 & 10.989 & 1.158 & 4.331 & 1.101 & 0.188 & 0.950 & 0.137 & 0.797 & 0.155 & 0.408 & 0.058 & 0.348 & 0.050 & 11.068 \\
\hline HJL16-1 & 20.029 & 37.769 & 4.197 & 16.199 & 4.086 & 0.791 & 4.276 & 0.674 & 4.167 & 0.803 & 2.125 & 0.301 & 1.843 & 0.264 & 41.310 \\
\hline HJL17-1 & 7.906 & 14.217 & 1.559 & 5.317 & 1.194 & 0.190 & 1.012 & 0.146 & 0.851 & 0.171 & 0.453 & 0.069 & 0.478 & 0.073 & 8.417 \\
\hline HJL18-1 & 2.484 & 4.317 & 0.434 & 1.535 & 0.371 & 0.063 & 0.340 & 0.051 & 0.310 & 0.060 & 0.166 & 0.024 & 0.155 & 0.023 & 4.754 \\
\hline HJL18-2B & 5.614 & 10.273 & 1.134 & 4.163 & 1.001 & 0.184 & 0.950 & 0.142 & 0.837 & 0.158 & 0.419 & 0.060 & 0.363 & 0.052 & 11.552 \\
\hline HJL18-4 & 8.459 & 15.028 & 1.633 & 6.064 & 1.537 & 0.274 & 1.488 & 0.217 & 1.253 & 0.247 & 0.681 & 0.097 & 0.586 & 0.081 & 19.178 \\
\hline MJB-04 & 1.610 & 3.069 & 0.329 & 1.190 & 0.290 & 0.050 & 0.269 & 0.039 & 0.237 & 0.048 & 0.128 & 0.018 & 0.118 & 0.017 & 3.493 \\
\hline MJB-09 & 1.369 & 2.811 & 0.313 & 1.079 & 0.250 & 0.040 & 0.211 & 0.030 & 0.171 & 0.032 & 0.081 & 0.012 & 0.076 & 0.011 & 1.597 \\
\hline MJB-11 & 0.586 & 1.102 & 0.124 & 0.432 & 0.101 & 0.016 & 0.090 & 0.013 & 0.075 & 0.014 & 0.037 & 0.005 & 0.033 & 0.004 & 0.828 \\
\hline GX-06 & 3.521 & 6.006 & 0.676 & 2.564 & 0.680 & 0.119 & 0.639 & 0.095 & 0.575 & 0.112 & 0.300 & 0.041 & 0.248 & 0.035 & 10.765 \\
\hline GX-08 & 3.008 & 5.146 & 0.540 & 1.904 & 0.481 & 0.087 & 0.450 & 0.071 & 0.440 & 0.088 & 0.231 & 0.031 & 0.190 & 0.027 & 8.385 \\
\hline GX-10 & 3.118 & 5.563 & 0.672 & 2.492 & 0.607 & 0.109 & 0.596 & 0.086 & 0.514 & 0.101 & 0.270 & 0.039 & 0.239 & 0.034 & 7.914 \\
\hline HJL12-2 & 3.962 & 6.504 & 0.699 & 2.604 & 0.698 & 0.113 & 0.632 & 0.089 & 0.528 & 0.100 & 0.270 & 0.038 & 0.226 & 0.033 & 8.368 \\
\hline HJL13-3A & 3.954 & 7.405 & 0.884 & 3.180 & 0.800 & 0.128 & 0.714 & 0.106 & 0.633 & 0.122 & 0.326 & 0.048 & 0.309 & 0.045 & 6.989 \\
\hline HJL13-5 & 9.680 & 19.013 & 2.354 & 9.098 & 2.301 & 0.454 & 2.206 & 0.342 & 1.972 & 0.379 & 0.945 & 0.133 & 0.832 & 0.115 & 20.192 \\
\hline HJL14-1 & 2.982 & 5.703 & 0.669 & 2.513 & 0.662 & 0.110 & 0.600 & 0.089 & 0.542 & 0.107 & 0.294 & 0.041 & 0.238 & 0.032 & 9.297 \\
\hline
\end{tabular}

The REE data from citation [40]. 
The REE composition of the precursor limestone would not be changed much during the dolomitization by the ancient seawater [46,47], and still inherits the REE component characteristics of the ancient seawater. If the diagenetic system is not closed, the carbonate formed or modified by other external fluids must have also borne the imprint of these fluids, which will be a good clue for tracing the diagenetic fluids. In the case of dolomites, the addition of external diagenetic fluids would cause changes in the values of the temperature, pressure, $\mathrm{pH}$ and the Eh of matrix limestone and pore water, while the stability of the rare earth elements would also change and induce the activation of REEs [48]. The continuous fluid action resulted in a higher water/rock ratio. Then the exchange of REEs between the rock and the fluid was achieved by the sufficient fluid-rock interaction $[46,48]$. Therefore, the alteration of various liquids and the selective leaching of REEs in the rock would significantly affect the composition of the REEs in the rock so that it would exhibit different characteristics of the REE distribution. These characteristics could not only reflect the source of the fluid and its geochemical properties to a certain extent but also trace the later fluid actions. The REE discrimination model of different fluid processes was established for that purpose [44].

Different types of carbonate rocks have different REE contents. The total contents of REEs in the limestone and dolomite from the study area were relatively low. Except for one dolomite sample, the values of other samples were all less than $70 \mathrm{ppm}$, and the average value of the limestone and three types of dolomites were all less than $40 \mathrm{ppm}$. In the sample of the GWSF, the average value of REEs in limestone was $19.9 \mathrm{ppm}$, and the total amount of REEs in FMD was concentrated on 2.1-30.3 ppm, with an average of 19.9 ppm. The total amount of REEs in FCD was mainly concentrated on 10.6-39.8 ppm, with an average of $26.4 \mathrm{ppm}$ eliminating an abnormally high value; the average value of REEs in MCD was 24.7 ppm eliminating an abnormally high value, similar to that of FCD.

To change the total content of REEs, there must be a high water-rock ratio. Under normal circumstances, it is not easy to achieve. Most natural fluids (including seawater, atmospheric water, groundwater, etc.) have a very low content of REEs, generally ranging from $10^{-12}$ to $10^{-10} \mathrm{ppm}$. Simultaneously, the hydrothermal fluid contained an especially high content of REEs $\left(10^{-6} \sim 10^{-12} \mathrm{ppm}\right)$; thus, the lower water-rock ratio might increase the total content of REEs in carbonate rock after dolomitization. However, the total amount of REEs in the MCD did not increase significantly, indicating that the hydrothermal fluid did not affect the MCD. The REE assemblage patterns of the $\mathrm{D}_{2} \mathrm{~g}$ dolomites were from North America Shale Composite that normalized in the northwestern Sichuan Basin [49].

\subsubsection{Isotopes of $\mathrm{C}, \mathrm{O}$ and $\mathrm{Sr}$}

Isotopic compositions of carbon, oxygen and strontium are presented in Table 1 and Figure 7. These are often used to indicate the sources of diagenetic fluid and the sedimentary environments for carbonate rocks. The fluid sources of different types of dolomites and their characteristics were discussed in detail. The $\delta^{13} \mathrm{C}$ value of the Middle Devonian seawater in western Sichuan was $-0.75 \%$ o $2.67 \%$, and the $\delta^{18} \mathrm{O}_{\mathrm{PDB}}$ value was $-7.60 \%$ o $-4.58 \%$ o [50,51]. The carbon and oxygen isotope analysis results of this study were compared to those of previous studies. These results were consistent with each other $[33,38,50]$, which were also consistent with that in other regions of the world [52].

The $\delta^{13} \mathrm{C}$ values of the limestone samples of the $\mathrm{D}_{2} \mathrm{~g}$ in the northwestern Sichuan Basin ranged from $-0.49 \%$ o to $-2.18 \%$, with an average of $-1.34 \%$, and the $\delta^{18} \mathrm{O}$ ranged from $-6.33 \%$ to $-5.65 \%$, with an average of $-5.99 \%$. The $\delta^{13} \mathrm{C}$ values of the FMD ranged from $0.96 \%$ to $3.36 \%$ with an average of $2.16 \%$, and the $\delta^{18} \mathrm{O}$ values of FMD ranged from $-5.22 \%$ to $-0.59 \%$ with an average of $-2.4 \%$. The $\delta^{13} \mathrm{C}$ values of the FCD varied in the range of $-2.56 \%$ o $3.98 \%$, with the average value of $0.87 \%$, the FCD's $\delta^{18} \mathrm{O}$ range was $-9.48 \% \sim 1.58 \%$, with the average of $-4.09 \%$. The $\delta^{13} \mathrm{C}$ values of MCD spanned from $1.66 \%$ o to $2.42 \%$, with the average value of $2.07 \%$, and the $\delta^{18} \mathrm{O}$ values of the MCD were between $-7.39 \%$ o to $-6.12 \%$, with an average of $-6.51 \%$. 


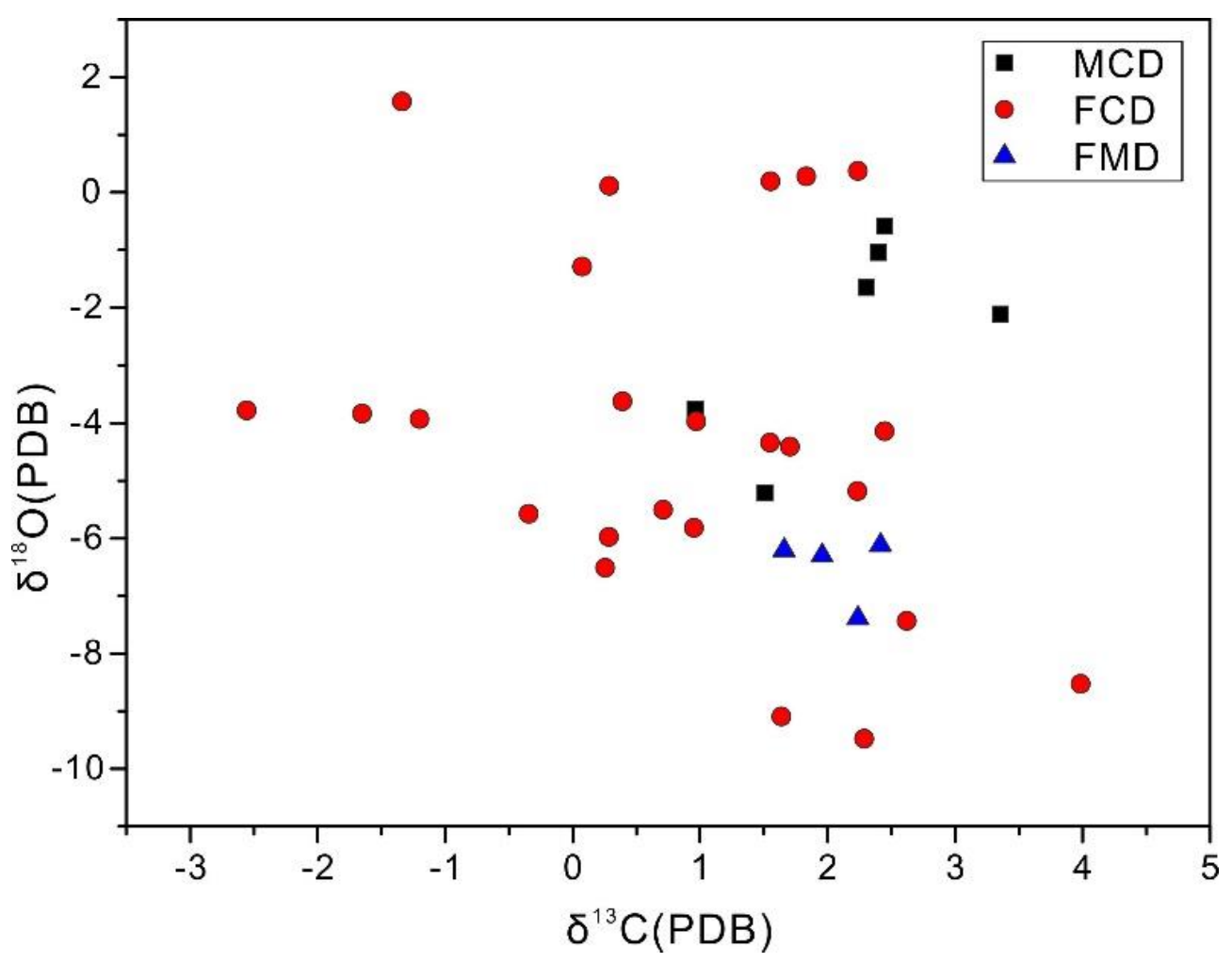

Figure 7. Cross-plot of $\delta^{13} \mathrm{C}$ and $\delta^{18} \mathrm{O}$ values for dolomites. FMD: Fine-microcrystalline dolomite; FCD: Fine crystalline dolomite; MCD: Medium crystalline dolomite.

The ${ }^{87} \mathrm{Sr} /{ }^{86} \mathrm{Sr}$ values of the limestone and dolomite all fell within a relatively wide range from 0.70809 to 0.71055 (Figure 8 ). The ${ }^{87} \mathrm{Sr} /{ }^{86} \mathrm{Sr}$ ratios varied from 0.70857 for Limestone, 0.70809 for FMD, 0.70814 to 0.70917 for FCD, and 0.70827 to 0.71055 for MCD.

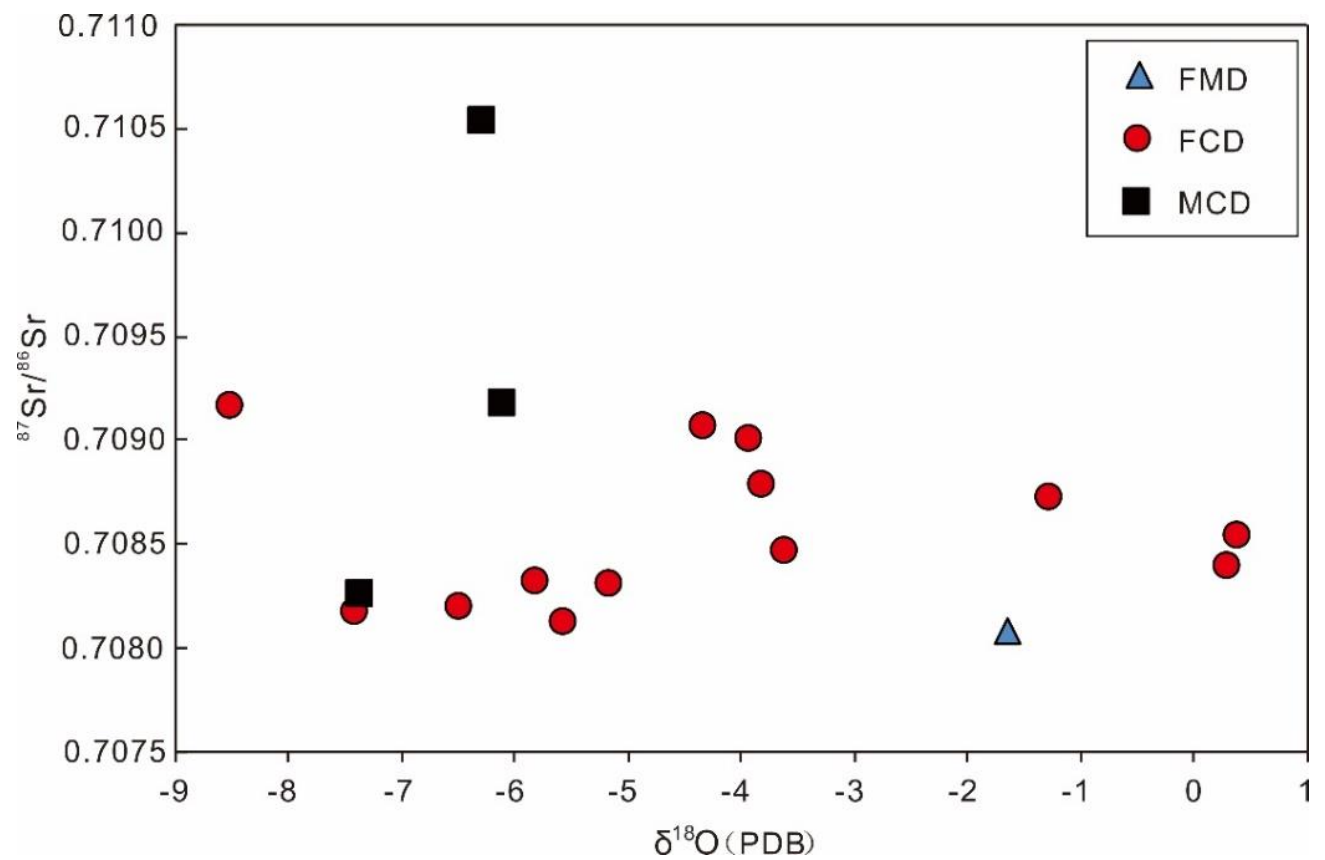

Figure 8. Cross-plot of ${ }^{87} \mathrm{Sr} /{ }^{86} \mathrm{Sr}$ and $\delta^{18} \mathrm{O}$ values for dolomites. FMD: Fine-microcrystalline dolomite; FCD: Fine crystalline dolomite; MCD: Medium crystalline dolomite. 


\section{Discussion}

\subsection{Dolomitization Fluid's Properties}

It has been determined that the sources and characteristics of dolomitization fluids were the keys to identifying the genesis of dolomites. Normally, the sources of dolomitization fluids were ordinary seawater [53,54], evaporatively concentrated seawater [7], a mixture of atmospheric fresh water and seawater [55], formation water [56] and deep hydrothermal fluids [57]. There was no evidence of addition of atmospheric freshwater in the study area, such as the geopetal structure. The overall brightness of CL was dark, and the $\delta^{13} \mathrm{C}$ value of dolomite didn't decrease due to the addition of terrestrial carbon, indicating that the dolomitization fluid was not mixed with atmospheric freshwater $[1,58]$. The contents of Sr in the dolomites of GWSF were low, and the negative Eu anomalies were not consistent with the characteristics of hydrothermal dolomite. The rare earth distribution patterns of different dolomites were consistent with that of the limestone. The above analysis concluded that the source of dolomitization fluid was the ancient seawater during diagenesis.

\subsection{Origin of Dolomite}

It was concluded that the dolomite in the study area mainly underwent penecontemporanous seepage-reflux dolomitization, early shallow buried dolomitization and late shallow buried dolomitization.

At the penecontemporanous seepage-reflux dolomitization stage, the lithology was mainly composed of FMDs and FCDs. The original structure was well preserved and obviously contained the laminar algal, bioclastic, etc. The CL showed mainly dark-red light, and some of the well euhedral dolomites exhibited the obviously bright edges, which were caused by multiple seepage-reflux of recirculating fluid. The bio-particles underwent selective dissolution and formed intra-granular dissolved pores. The dolomite formed at penecontemporaneous seepage-reflux stage was mainly developed in the tidal flat of the restricted platform (Figure 9). It was filled with bitumen and dolomite. Its content of $\mathrm{Sr}$ was higher, and the content of $\mathrm{Mn}$ was lower. Its value of $\delta^{18} \mathrm{O}$ was higher than that of limestone, which reflected the strong evaporation. The total REE content and the distribution curve of REE were similar to the limestone, which was influenced by the action of seawater in the same period. The interpretations above were also supported by the ${ }^{87} \mathrm{Sr} /{ }^{86} \mathrm{Sr}$ ratios $(0.70801)$ of FMD, comparable to the value of limestone (0.70857) and the typical ${ }^{87} \mathrm{Sr} /{ }^{86} \mathrm{Sr}$ values $(0.7088-0.7092)$ for the Middle Devonian seawater. In general, various characteristics reflected that the FCD formed by penecontemporaneous seepage-reflux with strong evaporation. The dolomitization fluid was the coeval seawater, and the evaporated seawater in the same period provided the rich content of $\mathrm{Mg}^{2+}$.

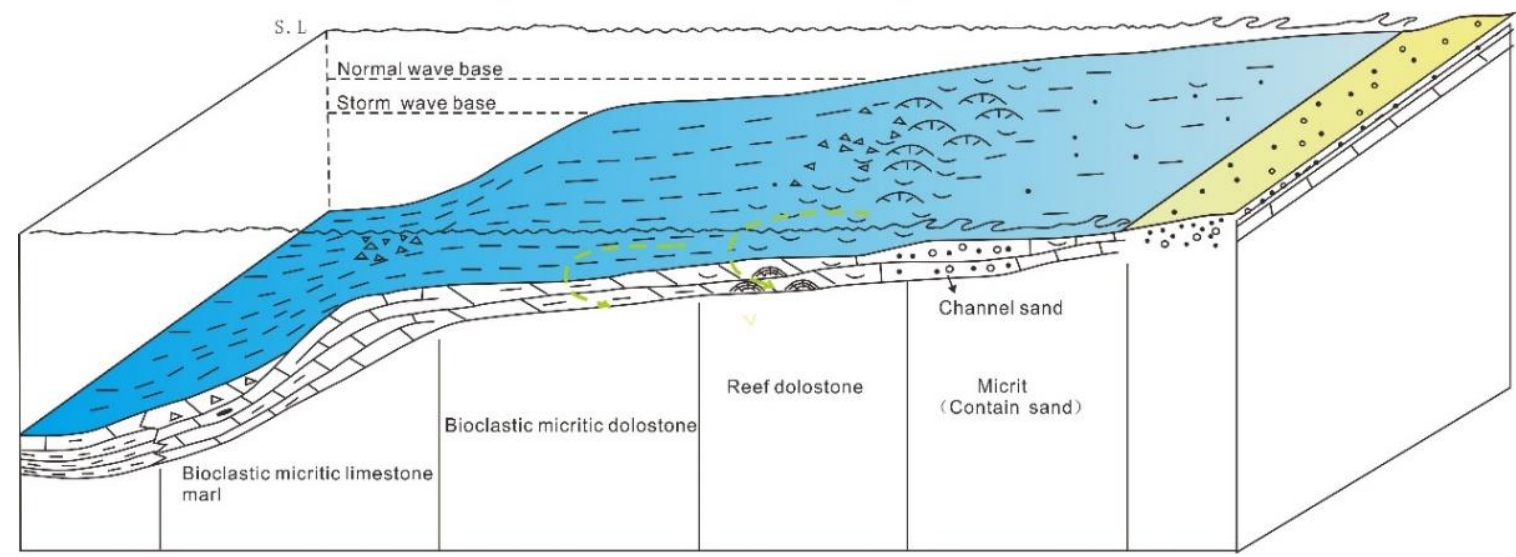

Figure 9. The deposition and proposed dolomitization process of $\mathrm{D}_{2} \mathrm{~g}$ in the northwestern Sichuan Basin. The sedimentary facies mainly consisted of tidal flats, platforms, and restricted sea, and the GWSF developed algal limestone (reef dolostone) and bioclastic limestone (dolomite). 
The early shallow buried dolomitization was mainly developed in the organic reef facies of platform margins and the bank of intra-platform. Fine crystals dominated the lithology, the order degree was high, and the dolomite was relatively stable. Typical karst breccia, bioclastic, larger organisms, and oolites were all dolomitized in a relatively slow process. The residual structure of raw scum was common, so it could be further divided into bioclastic dolomite, oolite dolomite, breccia dolomite and so on. The $\mathrm{Sr}$ content of the FMD was lower than that in the FCD, while the Mn content was higher to the FCD. The REE distribution curve showed the same distribution pattern as those of the limestone and FMD, so the diagenesis system was considered to be relatively closed. The dolomitization fluid was the Middle Devonian seawater in the strata, and most of them were recrystallized by the penecontemporaneous seepage-reflux dolomite. The $\delta^{18} \mathrm{O}$ of FCD was lower than the FMD, and was higher than the seawater in the same period. As the diagenesis system was relatively closed, this phenomenon was mainly caused by the increase of the formation depth. Combining the hydrocarbon filling time with the cutting relationship of fractures, the FCD was considered to be formed in the shallow burial stage. Still, the temperature was relatively not high, which led to the recrystallization of the FMD. The ${ }^{87} \mathrm{Sr} /{ }^{86} \mathrm{Sr}(0.70814-0.70917)$ values of FCD were also consistent with those of host limestone (0.70857) and the Middle Devonian seawater (0.7088-0.7092) [52], further attesting to coeval seawater as the dolomitization fluid, which was responsible for the formation of the FCD as documented above. Non-selective dissolution in the burial diagenetic stage based on structural fractures and pre-existing pores, then generated fluid flowing along the fracture-hole system and expanding the original pores or fractures into intergranular dissolved pores. At this stage, the dissolution was relatively weak, forming a relatively small number of dissolved holes.

Its lithology was mainly MCD at late shallow buried dolomitization stage, and were larger and coarser and showed more curved crystals, always with a hypidiomorphic structure. Mainly, its order degree was lower than that of FMD and FCD, and the dolomite was characterized by relatively fast growth in the later stage. The fossils and breccia were rare, and only the biological phantom could be faintly seen. The CL commonly showed brighter porphyritic light. The content of $\mathrm{Sr}$ was the lowest, while the content of $\mathrm{Mn}$ was similar to that of FCD. The distribution curve of REE showed the same distribution pattern as those of limestone, FMD and FCD, indicating the action system was relatively closed. The dolomitization fluid was the Middle Devonian seawater trapped in the stratum, and the dolomitization time was close to that of the early shallow buried dolomite. The MCD was formed by recrystallization of FCD. Its $\delta^{18} \mathrm{O}$ value was more negative than that of FCD and seawater in the same period. Combined with the burial history of Kuang 2 and the distribution of paleothermal before and after the Emeishan activity [59], it was believed that this stage of dolomitization might be affected by the Middle Permian Emeishan large igneous province and the higher geothermal gradient provided to the FCD. The higher ground temperature enhanced the water-rock reaction, so the FCD rapidly recrystallized to form MCD. This interpretation was also supported by the ${ }^{87} \mathrm{Sr} /{ }^{86} \mathrm{Sr}$ ratios (0.70827 to 0.71055$)$ of MCD, which was higher than other types of dolomites and host limestone (Figure 8). In addition, enhanced fluid-rock interactions at depths would be likely to contribute to the $\delta^{18} \mathrm{O}$ decreases and ${ }^{87} \mathrm{Sr} /{ }^{86} \mathrm{Sr}$ increases [2,60]. At the same time, relatively clean fillings were formed in the early dissolution pores and cracks, and some were saddle dolomites, which presented high temperature characteristics. In general, the dolomite formed by the late shallow buried dolomitization was characterized by filling and cementation, which were destructive diagenesis.

\section{Conclusions}

(1) The dolomites of the GWSF in the northwestern Sichuan Basin were divided into FMD, FCD, and MCD. These dolomitization were more thorough, while the transitional type of dolomites not developed. 
(2) By combining the mineralogical, elemental, and isotopic characteristics of different types of dolomites, it was concluded that the dolomites in the study area mainly underwent penecontemporanous seepage-reflux dolomitization, early shallow buried dolomitization, and late shallow buried dolomitization.

(3) The thick dolomite strata in the study area were mainly controlled by the sedimentary facies. The limited platform included a wide distribution zone in the study area. The evaporation in the restricted platform was strong, the water body was quiet. The microcrystalline dolomite and FMD which formed at the earlier stage, provided a solid $\mathrm{Mg}^{2+}$ material basis for the continued occurrences of dolomitization in later stage. They were mainly composed of FCD and MCD at the reef beach on the platform margin and platform shoal.

(4) CL and REE analysis indicated that the FMD, FCD, and MCD were all dolomitized by the early diagenesis fluids from the Middle Devonian ancient seawater. The latter two dolomites both recrystallized from the former one during the deep burial.

Author Contributions: Conceptualization, S.H. and M.H.; methodology, S.H. and A.C.; software, Y.Y.; investigation, S.H., B.Z., Y.D. and S.X.; writing-original draft preparation, S.H.; writing-review and editing, M.H.; visualization, A.C.; supervision, M.H.; funding acquisition, M.H. All authors have read and agreed to the published version of the manuscript.

Funding: This work was supported by grants from the project of Northwest Sichuan Division, PetroChina Southwest Oil and Gas Field Company (No. XNS05JS2016-86).

Data Availability Statement: Not applicable.

Acknowledgments: We thank Di Yang from the State Key Laboratory of Oil and Gas Reservoir Geology and Exploitation (Chengdu University of Technology) for Sr isotope analysis. Deyan Zhang from the University of Hanover is appreciated for grammar revisions.

Conflicts of Interest: The authors declare no conflict of interest.

\section{References}

1. Warren, J.K. Dolomite: Occurrence, evolution and economically important associations. Earth Sci. Rev. 2005, 2, 1-81. [CrossRef]

2. Gregg, J.M.; Bish, D.L.; Kaczmarek, S.E.; Machel, H.G. Mineralogy, nucleation and growth of dolomite in the laboratory and sedimentary environment: A review. Sedimentology 2015, 62, 1749-1769. [CrossRef]

3. Mueller, M.; Igbokwe, O.A.; Walter, B.; Pederson, C.L.; Riechelmann, S.; Richter, D.K.; Albert, R.; Gerdes, A.; Buhl, D.; Neuser, R.D.; et al. Testing the preservation potential of early diagenetic dolomites as geochemical archives. Sedimentology 2020, 67, 849-881. [CrossRef]

4. He, Y.; Liu, B.; Qin, S. Study on the dolomitization and dolostone genesis. Acta Sci. Nat. Univ. Pekin. 2010, 46, 1010-1020.

5. Adams, J.E.; Rhodes, M.L. Dolomitization by seepage refluxion. AAPG Bull. 1960, 44, 1912-1920.

6. Bush, P.R. Some Aspects of the Diagenetic History of the Sabkha in Abu Dhabi, Persian Gulf. In The Persian Gulf; Purser, B.H., Ed.; Springer: New York, NY, USA, 1973; pp. 395-407.

7. Mckenzie, J.A.; HSü, K.J.; Schneider, J.F. Movement of subsurface waters under the Sabkha, Abu Dhabi, UAE, and its relation to evaporative dolomite genesis. AAPG Bull. 1980, 28, 11-30.

8. Badiozamani, K. The Dorag dolomitization model-application to the Middle Ordovician of Wiscons. J. Sediment. Petrol. 1973, 43, 965-984.

9. Meister, P.; Bernasconi, S.M.; Vasconcelos, C.; McKenzie, J.A. Sea-level changes control diagenetic dolomite formation in hemipelagic sediments of the Peru Margin. Mar. Geol. 2008, 252, 166-173. [CrossRef]

10. Adams, A.; Diamond, L.W.; Aschwanden, L. Dolomitization by hypersaline reflux into dense groundwaters as revealed by vertical trends in strontium and oxygen isotopes: Upper Muschelkalk, Switzerland. Sedimentology 2019, 66, 362-390. [CrossRef]

11. Matters, B.W.; Mountjoy, E.W. Burial dolomitization of the Upper Devonian Miette buildup, Jasper National Park, Alberta. In Concepts and Models of Dolomitization; Zenger, D.H., Dunham, J.B., Ethington, R.L., Eds.; SEPM Special Publication: Tulsa, OK, USA, 1980; Volume 28, pp. 259-297.

12. Haedie, L.A. Dolomitization: A critical view of some current views. J. Sediment. Res. 1987, 57, $166-183$.

13. Montaenz, I.P. Late diagenetic dolomitization of Lower Ordovician, Upper Knox Carbonates: A record of the hydrodynamic evolution of the southern Appalachian Basin. AAPG Bull. 1994, 78, 1210-1239.

14. Vahrenkamp, V.C.; Swart, P.K. Late Cenozoic Dolomites of the Bahamas: Metastable Analogues for the Genesis of Ancient Platform Dolomites; Springer: Berlin/Heidelberg, Germany, 1994; Volume 21, pp. 133-153.

15. Davies, G.R.; Smith, L.B., Jr. Structurally controlled hydrothermal dolomite reservoir facies: An overview. AAPG Bull. 2006, 90, 1641-1690. [CrossRef] 
16. Zheng, H.F.; Ma, Y.S.; Chi, G.Y.; Qing, H.R.; Liu, B.; Zhang, X.F.; Sheng, Y.C.; Liu, J.Q.; Wang, Y.C. Stratigraphic and Structural Control on Hydrothermal Dolomitization in the Middle Permian Carbonates, Southwestern Sichuan Basin (China). Minerals 2019, 9, 32. [CrossRef]

17. Chen, P.; Fu, M.Y.; Deng, H.C.; Xu, W.; Wu, D.; He, P.W.; Guo, H.W. The Diagenetic Alteration of the Carbonate Rocks from the Permian Qixia Formation as Response to Two Periods of Hydrothermal Fluids Charging in the Central Uplift of Sichuan Basin, SW China. Minerals 2021, 11, 1212. [CrossRef]

18. Vasconcelos, C.; Mckenzie, J.A.; Bernasconi, S.; Grujic, D.; Tien, A.J. Microbial mediation as a possible mechanism for natural dolomite formation at low temperatures. Nature 1995, 377, 220-222. [CrossRef]

19. Sánchez-Román, M. Aerobic microbial dolomite at the nanometer scale: Implications for the geologic record. Geology 2008, 36, 879-882. [CrossRef]

20. Petrasha, D.A.; Bialik, O.M.; Bontognali, T.R.R.; Vasconcelos, C.; Roberts, J.A.; McKenzie, J.A.; Konhauser, K.O. Microbially catalyzed dolomite formation: From near-surface to burial. Earth-Sci. Rev. 2017, 171, 558-582. [CrossRef]

21. Vandeginste, V.; Snell, O.; Hall, M.R.; Steer, E.; Vandeginste, A. Acceleration of dolomitization by zinc in saline waters. Nat. Commun. 2019, 10, 1851. [CrossRef]

22. Mei, M. Brief introduction of "dolostone problem" in sedimentology according to three scientific ideas. J. Palaeogeogr. 2006, $14,1-12$.

23. Wang, Z.F.; Huang, K.K.; Zhang, D.J.; You, L.; Liu, X.Y.; Luo, W. Maturation of Neogene dolomite from Xuande Atoll of Xisha archipelago, the South China Sea. Mar. Pet. Geol. 2018, 92, 51-64. [CrossRef]

24. Ning, M.; Lang, X.G.; Huang, K.J.; Li, C.; Huang, T.Z.; Yuan, H.L.; Xing, C.C.; Yang, R.Y.; Shen, B. Towards understanding the origin of massive dolostones. Earth Planet. Sci. Lett. 2020, 545, 116403. [CrossRef]

25. Tang, J.; Dietzel, M.; Böhm, F.; Köhler, S.J.; Eisenhauer, A. $\mathrm{Sr}^{2+} / \mathrm{Ca}^{2+}$ and ${ }^{44} \mathrm{Ca} /{ }^{40} \mathrm{Ca}$ fractionation during inorganic calcite formation: II. Ca isotopes. Geochim. Cosmochim. Acta 2008, 72, 3733-3745. [CrossRef]

26. Gussone, N.; Schmitt, A.D.; Heuser, A.; Wombacher, F.; Dietzel, M.; Tipper, E.; Schiller, M. Calcium Stable Isotope Geochemistry; Springer: Berlin/Heidelberg, Germany, 2016.

27. Murray, S.T.; Swart, P.K. Evaluating formation fluid models and calibrations using clumped isotope paleothermometry on Bahamian dolomites. Geochim. Cosmochim. Acta 2017, 206, 73-93. [CrossRef]

28. Polyak, V.; Provencio, P.; Asmerom, Y. U-Pb dating of speleogenetic dolomite: A new sulfuric acid speleogenesis chronometer. Int. J. Speleol. 2016, 45, 103-109. [CrossRef]

29. Manche, C.J.; Kaczmarek, S.E. Evaluating reflux dolomitization using a novel high-resolution record of dolomite stoichiometry: A case study from the Cretaceous of central Texas, USA. Geology 2019, 47, 586-590. [CrossRef]

30. Gong, D.M. Conodonts from the top of Guanwushan formation of devonian system in Majiaoba. J. Chengdu Inst. Geol. 1990, $17,10-17$.

31. Xian, S.Y.; Chen, J.R.; Wan, Z.Q. Devonian ecostratigraphy, sequence stratigraphy and sea-level changes in Ganxi, Longmen Mountain area, Sichuan. Sediment. Facies Palaeogeogr. 1995, 15, 1-47.

32. Liu, W. Devonian sequence stratigraphy and relative sea level changes in Longmenshan Area, Sichuan. J. China Univ. Geosci. 1996, 7, 60-70.

33. Zheng, R.C.; Liu, W.J.; Li, X.H.; Chen, Y.R.; Wang, H.F. The genetic types and their sequence stratigraphic significances of Devonian dolostones in Longmen Mountains. J. Miner. Petrol. 1996, 16, $28-37$.

34. Zheng, R.; Liu, W. Depositional systems and cyclic sequences of Pin Yipu Formation Longmenshan area. Acta Sedimentol. Sin. 1997, 15, 1-7.

35. Hou, H.F.; Wan, Z.Q.; Xian, S.Y. Devonian Stratigraphy, Paleontology and Sedimentary Faceis of Longmenshan, Sichuan; Geological Publishng House: Beijing, China, 1988. (In Chinese)

36. Chen, H.G.; Li, X.Q.; Yuan, H.L.; Huang, S.J.; Wang, K.Z. Carbon and oxygen isotope variations of Devonian seawater: Isotopic records from brachiopod shell. Acta Geosci. Sin. 2009, 30, 79-88.

37. Pang, Y.J.; Zhang, B.J.; Feng, R.W.; Wang, Y.R. Evolution of Devonian depositional environment in northern Longmenshan tectonic belt. Glob. Geol. 2010, 29, 561-568.

38. Zeng, Y.; Huang, S.; Kulle, H.; Schönfeld, M. The correlation between the dolomites and their forming conditions in the Guanwushan Formation (Middle Devonian) Ganxi, Sichuan, China. Acta Sedimentol. Sin. 1988, 6, 12-23.

39. Huang, S.J. The Cathodoluminescence and diagenesis of the carbonates of Guanwushan formation, Middle Devonian, Ganxi, Northwestern Sichuan. J. Chendu Univ. Technol. (Sci. Technol. Ed.) 1988, 15, 50-58.

40. Deng, Y.W.; Hou, M.C.; Chen, A.Q.; Ma, H.L.; Dong, Y.X.; Luo, W.; Huang, S.G. Ree Characteristics of Dolomites and Indication of Dolomitization Fluid in Guanwushan Formation, NW Sichuan Basin, China. J. Chendu Univ. Technol. (Sci. Technol. Ed.) 2018, 45, 282-291.

41. Huang, S.G.; Hou, M.C.; Xu, S.L.; Chen, A.Q.; Zhang, B.J.; Luo, W.; Chao, H.; Cai, P.C.; Deng, Y.W. Dolomitization Fluid and Genesis of Dolomite in the Devonian Guanwushan Formation in Upper Yangtze. In Advances in Science, Technology E Innovation; Springer: Berlin/Heidelberg, Germany, 2022. [CrossRef]

42. Shen, H.; Wang, H.; Wen, L.; Ma, H.; Li, Y.; Zhang, B. Natural gas exploration prospect in the Upper Paleozoic strata, NE Sichuan Basin. Nat. Gas Ind. 2016, 36, 11-21.

43. Sibley, D.F.; Gregg, J.M. Classification of dolomite rock textures. Sediment. Petrol. 1987, 57, 967-975. 
44. Hu, W.X.; Chen, Q.; Wang, X.L.; Cao, J. REE models for the discrimination of fluids in the formation and evolution of dolomite reservoirs. Oil Gas Geol. 2010, 31, 810-818.

45. Liu, J.Q.; Lin, J.S.; Feng, W.M.; Zhao, Z.; Huang, X.P. The REE geochemical characteristics of Middle-Upper Cambrian dolomite in Southeast Sichuan Basin and its significance: A case study of Changshutian profile in Bijie, Guizhou. Miner. Petrol. 2014, 34, 87-94.

46. Qing, H.; Mountjoy, E.W. Rare earth element geochemistry of dolomites in the Middle Devonian Presqu'ile barrier Westerm Canada Sedimentary Basin: Implications for fluid-rock ratios during dolomitization. Sedimentology 1994, 41, 787-804. [CrossRef]

47. Webb, G.E.; Nothdurft, L.D.; Kamber, B.S.; Kloprogge, J.T.; Zhao, J.X. Rare earth element geochemistry of scleractinian coral skeleton during meteoric diagenesis: A sequence through neomorphism of aragonite to calcite. Sedimentology 2009, 56, 1433-1463. [CrossRef]

48. Bau, M.; Dulski, P. Distribution of yttrium and rare-earth elements in the Penge and Kuruman iron-formations, Transvaal Supergroup, South Africa. Precambrian Res. 1996, 79, 37-55. [CrossRef]

49. Kawabe, I. Convex tetrad effect variations in REE abundances of "North American shale composite" and "Post-Archean Australian average shale". Geochem. J. 1996, 30, 149-153. [CrossRef]

50. Huang, S.J. A study on carbon and strontium isotopes of late Paleozoic carbonate rocks in the Upper Yangtze platform. Acta Geol. Sin. 1997, 1, 45-53.

51. Lu, W.C.; Cui, B.Q.; Yang, S.Q.; Zhang, P. Isotope stratigraphic curves of Devonian marine carbonates in Ganqi profile. Acta Sedimentol. Sin. 1994, 3, 12-20.

52. Veizer, J.; Ala, D.; Azmy, K.; Bruckschen, P.; Buhl, D.; Bruhn, F.; Carden, G.A.; Diener, A.; Ebneth, S.; Godderis, Y.J. ${ }^{87} \mathrm{Sr} /{ }^{86} \mathrm{Sr}, \delta^{13} \mathrm{C}$ and $\delta^{18} \mathrm{O}$ evolution of Phanerozoic seawater. Chem. Geol. 1999, 161, 59-88. [CrossRef]

53. Mazzullo, S.J.; Bischoff, W.D.; Teal, C.S. Holocene shallow subtidal dolomitization by near-normal seawater, northern Belize. Geology 1995, 23, 341-344. [CrossRef]

54. Sabagh, B.M.; Mahboubi, A.; Al-Aasm, I.; Moussavi-Harami, R.; Nadjafi, M. Multistage dolomitization in the Qal'eh Dokhtar formation (Middle-Upper Jurassic), Central Iran: Petrographic and geochemical evidence. Geol. J. 2018, 53, 22-44. [CrossRef]

55. Cander, H.S. An example of mixing-zone dolomite, middle Eocene Avon park formation, floridian Aquifer system. J. Sediment. Res. 1994, 64, 615-629.

56. Harrison, W.J.; Summa, L.L. Paleohydrology of the gulf of Mexico basin. Am. J. Sci. 1991, 291, 109-176. [CrossRef]

57. Mahboubi, A.; Nowrouzi, Z.; Al-Aasm, I.S.; Moussavi-Harami, R. Dolomitization of the silurian niur formation, tabas block, east central Iran: Fluid flow and dolomite evolution. Mar. Petrol. Geol. 2016, 77, 791-805. [CrossRef]

58. Machel, H.G.; Mountjoy, E.W.; Jones, G.D.; Rostron, B.J. Toward a sequence stratigraphic framework for the Frasnian of the Western Canada Basin. Bull. Can. Pet. Geol. 2002, 50, 332-338. [CrossRef]

59. Zhu, C.; Xu, M.; Yuan, Y.; Zhao, Y.; Shan, J.; He, Z.; Tian, Y.; Hu, S. Palaeogeothermal response and record of the effusing of Emeishan basalts in the Sichuan basin. Chin. Sci. Bull. 2010, 55, 949-956. [CrossRef]

60. Al-Aasm, I.S.; Packard, J.J. Stabilization of early-formed dolomite: A tale of divergence from two Mississippian dolomites. Sediment. Geol. 2000, 131, 97-108. [CrossRef] 